\title{
Molecular Characterization of Virulence and Antibiogram profile of Pseudomonas aeruginosa Isolated from Chronic Suppurative Otitis Media Patients, Al-Nasiriyah City, Iraq.
}

\author{
Muslim Dhahr Musa \\ Departement of Community Health AL- \\ Nasiryah Technical Institute/ Southern \\ Technical University \\ Thi-Qar/ Iraq \\ Email: muslim1983@stu.edu.iq \\ https://orcid.org/0000-0003-2648-400X
}

Scopus Author ID: 57219161284

https://doi.org/10.32792/utq/utjsci/v8/1/4

\begin{abstract}
This study was conducted to characterize the virulence of P.aeruginosa isolated from Chronic Suppurative Otitis Media (CSOM) in a particular area at the south of Iraq, Al-Nasiryah City. Conventional bacteriological methods were used to isolate and identify P.aeruginosa. Polymerase chain reaction (PCR) with a specific primer that targeting outer membrane Liporpotien $\mathrm{L}$ gene $(\mathrm{OprL})$ was used to detect P.aeruginosa. The following virulence genes were screened; ToxA, LasB and LasA. Results indicated that the majority of CSOM was attributed to bacterial infection $(83.4 \%)$ in comparison with only $\mathbf{2}(\mathbf{5 . 6 \%})$ were fungal infections. P.aeruginosa was the most predominant species (36.7\%) followed by S.aurues, Proteus Spp. and E.coli. Virulence profile revealed that all strains of $P$.aeruginos $a$ were harboring at least one virulence gene. ToxA gene was found in most strains (90.1\%) followed by LasB gene $(\mathbf{8 1 . 8 \%})$ and LasA gene $(63.6 \%)$. According to different combination of virulence genes, P.aeruginosa can be categorized into four genotypes with high prevalence $(63.6 \%)$ of the most virulent genotype (ToxA+LasA+Las B+) followed by genotype (ToxA+LasALas $B+)(18.6 \%)$ while the genotypes (ToxA+ LasA- Las B and ToxA+LasA-LasB-) were found in lowest percentage $(9.1 \%)$. Additionally, all strains were able to form a biofilm with varying propensity however, the strong biofilm strains were found in a high percentage $(\mathbf{7 2 . 7 \%})$ in genotype (ToxA+LasA+ Las $B+)$. Antibiogram analysis revealed that high resistance rate against otototic antibiotics including; Erythromycine, Ciprofloxacin(63\%), Gentamycin, Ofloxacin and Ceftriaxone were $(47.4 \%, 47.3 \%$ and $42.1 \%$ respectively). In conclusions, the P.aeruginosa causing CSOM in Al-Nasiriyah city is highly virulent and have a great ability to form biofilm, which could protect it from most commonly used antibiotics especially those used in Al-Nasiriyah, so it is highly recommended to seek for alternative treatment.
\end{abstract}

Keywords: P.aeruginosa, Otitis Media, Biofilm, Antibiogram, Iraq

\section{Introduction}

Chronic Suppurative Otitis Media (CSOM) defined as a chronic middle ear and mastoid cavity inflammation, characterized by perforated tympanic membrane and persistence ear discharge (otorrhea) which lasting two weeks according to the World Health Organization(WHO) definition (World Health Organization, 2003). The disease mainly occurs during the first 6 years of childhood life, usually as s sequel of failure or incomplete Acute Otitis Media (AOM) treatment (Li, Hotez, Vrabec, \& Donovan, 2015) however, occurring in the adults is not uncommon (Li et al., 2015; Orji FT, 2013; World Health Organization, 2003). The pathogenesis of CSOM has not yet understood however, the interaction between host factor (the abnormal function of Eustachian tube), environment, and microbial infection, thought to provide a fertile ground for the development of CSOM (Mittal et al., 2015b). Many bacterial species have implicated as the causative agents of CSOM including; Pseudomonase, Staphylococccus aureus, Proteues spp., Klebsiellia spp, and E.coli (Mittal et al., 2015a; Molla, Tiruneh, Abebe, \& Moges, 2019; World Health Organization, 2003). Studies that undertook the bacterial profile of CSOM from various parts of the world were almost agreed that most frequently encountered bacterium species in the CSOM were P.aeruginosa (Ettehad, G. H., Refahi, S., Nemmati, A., Pirzadeh, A. \& Daryani, 2006;Ahmad, 2013). It appears that there is a global consensus that P.aeruginosa is the most likely bacterial species that cause CSOM.

In particular, P.aeruginosa was blamed for the progressive destruction of middle ear tissues through its toxins and enzymes(World Health Organization, 2003). P.aeruginosa is a gram-negative bacterium that has high adaptability and intrinsic resistance to antibiotics, enables it to colonize a variety of settings(Gellatly \& Hancock, 2013). It has been proposed, that during otitis media, the ear environment became suitable for the colonization of P.aeruginosa. Once colonization of ear, it is 
difficult to eradicate, taking the advantage of its toxins and enzymes that damage the ear tissue. P.aeruginosa able to avoid host immune response through minimizing blood flow and forming a shell that protects themselves(Mittal et al., 2015a). P.aeruginosa has a number of exotoxins and enzymes that secreted passively or through secretion system, most importantly; exotoxin A (toxA), protease (lasA) and elastaese (lasB), all these virulence factors secreted via secretion system type II(Najafi, Kafil, Shokrian, \& Azimi, 2015a).

Recent studies have linked the pathogenesis of CSOM with biofilm production, biofilm firmly attached to damaged tissue and resist antibiotics(J.C. Post, P. Stoodley, L. Hall-Stoodley, 2004; Wang, J. C., Hamood, A. N., Saadeh, C., Cunningham, M. J., Yim \& Cordero, 2014). P.aeruginosa considered a model of biofilmproducing bacteria as it has been found in biofilm form in many infections including CSOM(Dohar et al., 2005). The therapeutic (antimicrobial drugs) choices for CSOM are becoming limited through the continued emergence of multidrug resistance strains of P.aeruginosa. Hence it is important to highlight the virulence and antimicrobial resistance of local strain of the P.aeruginosa. Thus, the overall aims of this study were to identify the virulence factors possessed by this bacterium, and looking for its antibiogram profile to provide the local physicians with best antimicrobial treatment recommendations.

\section{Materials and Methods}

\section{A. Study Design, Area and Population}

This hospital-based study was carried out in the Ear, Nose and Throat (E.N.T) clinic of Al-Habobbi hospital at Al-Nasiriyah city which is geographically located at the south of Iraq with estimated population 400249. The ENT clinic health services covering the entire Al-Nasiriyah city. Attending this clinic was most often for Otitis Media (O.M) reason. The study population was the out-patients with ear discharge for at least two weeks and had perforated tympanic membrane as diagnosed with an otoscope by otologist of the E.N.T Clinic. Exclusion criteria were; patients with intact tympanic membrane, patients with tympanostomy tube, and patients who had antibiotics therapy for last three days before attending the Clinic.

\section{B. Sample Collection}

Samples collection was conducted in the period extended from October to December 2019 on daily surveillance for CSOM patients, during this period 36 ear swabs were aseptically collected by the clinician at ENT clinic, following the standard technique as follows: the auditory canal was firstly cleaned with $70 \%$ ethanol then sterile swab was inserted carefully without touching the auditory canal until reached the tympanic membrane. The swabs were directly transported to Microbiology lab at Technical Institute-Southern Technical University at Al-Nasiriya City within less than one hour, for bacteriological cultivation, identification.

\section{Bacteriological Cultivation and Identification}

Swabs were streaked on Blood Agar (BA) medium and incubated aerobically for 24 hours at $37 \mathrm{C}^{\circ}$. The blood agar plates that showed no bacterial growth for 48 hours were discarded as negative growth. On blood agar plate, the colonies that showed positive Oxidase test were picked carefully and subcultured on nutrient agar medium and incubated at $37 \mathrm{C}^{\circ}$ for 24 hours. Identification was accomplished based on pyocyanin production on nutrient agar medium plates, gram staining, growth at $42 \mathrm{C}^{\circ}$ and API20NE (Biomereux, France). The identified isolates were subcultured in Brain Heart Infusion Broth (BHIB) for further works.

\section{Molecular Identification and Screening for Virulence Factors}

\section{- Genomic DNA Extraction}

The brain heart infusion broth cultures were subjected to DNA extraction using DNA extraction Kit (Jenaid DNA extraction kit, Thailand). The amount and purity of extracted DNA were estimated using NanoDrop.

\section{- Amplification of Identification and Virulence Genes}

For identification of P.aeruginosa species, Oprl L gene which encoded for outer membrane Lipoprotein was used. For screening of virulence factors the following genes; ToxA (coding for Exotoxin A), LasB (coding for elastase) and LasA (coding for protease) were screened using Polymerase Chain Reaction (PCR) with specific primers whose sequences, annealing temperature and product size presented in table(1). The PCR reactions were done in $0.2 \mathrm{ml}$ tube containing; $5 \mu \mathrm{l}$ template DNA, $0.5 \mu 1$ (10 Pico mole) of each forward and reverse primer, $5 \mu 1$ of Premix (AccuaPure, Bioneer Korea) and the remaining of volume was completed with deionized distal water. The thermo-cycler machine (Bioneer Korea) was set to fulfill the thermo-cycle conditions presented in the table(1). Visualization of the product was conducted by transferring $10 \mu \mathrm{l}$ of the products to previously prepared wells in agarose gel(2\%), stained with Ethidium bromide. Electrophoresis was conducted under $105 \mathrm{~V}$ and $400 \mathrm{~mA}$ for 55 Minutes. The product sizes were estimated in comparison with molecular markers (1 Kpb and $10 \mathrm{Kbp}$ Ladder) and Image Analyzer version 0.4 software for precise determination of product size. Gel documentation device (Atta, Japan) was used for photographing and analysis.

\section{E. Antibiogram Analysis}

All P.aerugionsa isolates were tested against 8 commonly used antibiotics to treat CSOM including those prescribed at ENT clinic of Al-Habobbi hospital. Kirby-Bauer, disk diffusion method was conducted using Muller-Hinton Agar medium. The following antibiotics

are used;Piperacillintazobactam,Amikacin $(10 \mu \mathrm{g})$, Gentamycin(10 $\mu \mathrm{g}), \mathrm{C}$ eftriaxone,Erythromycin $(15 \mu \mathrm{g})$, Ciprofloxcin(5 $\mu \mathrm{g})$, Ofloxacin(30 $\mu \mathrm{g})$, co-trimoxazole $(1.25 / 23.75 \mu \mathrm{g})$. The results were recorded as sensitive and resistance according to criteria of CLSI2018(27th ed. CLSI supplement M100. Wayne, 2017).

\section{F. Biofilm assay}

Microtiter plate protocol was employed to quantitatively determine the in vitro biofilm production as described by Igbinosa et al .,(2015). An overnight P.aeruginosa brain heart infusion(BHI) broth culture was prepared, the cell density was adjusted to 0.2 of optical density $(\mathrm{OD}=600)$ using a spectrophotometer. $20 \mu \mathrm{l}$ of bacterial broth was transferred to plate wells containing $180 \mu \mathrm{l}$ BHI and $20 \mu \mathrm{l}$ of D.W was added to negative control wells. The plate was incubated at 37C for 24 hours. Using a multichannel pipette, the wells were aspirated and washed three times with phosphate buffered slain (PBS,PH=7.4). Crystalviolate $(1 \%)$ was added $(200 \mu \mathrm{l})$ to each well including control negative and lets stand for 30 minutes. By the end of incubation, the stain was removed by multichannel pipette and the wells were washed three times with PBS. Plate was allowed to air dry at room temperature, then $150 \mu$ l absolute ethanol was added to each well for removing extra stain. The plate inverted on filter paper to remove the ethanol. Cell adherence was measured by microliter plate reader (Biotech, USA) at wave length $570 \mathrm{~mm}$. biofilm propensity was recorded as in comparison with control negative value as follow; non biofilm (OD of isolate $\geqslant$ OD of control negative), weak biofilm (OD control negative < OD of 
isolate $<0.1$ ), moderate biofilm (OD isolate $>0.12$ ), strong biofilm ( OD isolate $>1$ ).

Table (1): The primers sequences and thermo-cycle conditions for amplification of targeted identification and virulence genes of

\begin{tabular}{|c|c|c|c|c|}
\hline $\begin{array}{c}\text { Type of } \\
\text { microbial } \\
\text { infection }\end{array}$ & No. & Species & Total & P-Value \\
\hline \multirow{2}{*}{$\begin{array}{c}\text { Mono- } \\
\text { microbial } \\
\text { infections }\end{array}$} & \multirow{2}{*}{$\begin{array}{c}14 \\
(46.7 \%)\end{array}$} & P.aeruginiosa & $8(57.1 \%)$ & \multirow{2}{*}{$\mathrm{P}>0.05$} \\
\hline & & S.aureus & $6(42.8 \%)$ & \\
\hline \multirow{2}{*}{$\begin{array}{c}\text { Poly- } \\
\text { microbial } \\
\text { infections }\end{array}$} & \multirow{2}{*}{$\begin{array}{c}16 \\
(53.4 \%)\end{array}$} & $\begin{array}{c}\text { With } \\
\text { P.aeruginosa } \\
\end{array}$ & $\begin{array}{c}3 \\
(18.7 \%) \\
\end{array}$ & \multirow{2}{*}{$\mathrm{P}<0.05$} \\
\hline & & $\begin{array}{c}\text { Without } \\
\text { P.aeruginosa }\end{array}$ & $\begin{array}{c}13(81.3 \% \\
)\end{array}$ & \\
\hline Total & & & 30 & \\
\hline
\end{tabular}

\begin{tabular}{|c|c|c|c|c|c|}
\hline $\begin{array}{c}\text { Gene } \\
\text { s }\end{array}$ & Sequences & 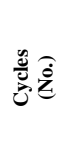 & 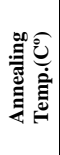 & 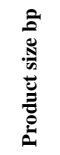 & $\begin{array}{c}\text { Referenc } \\
\mathrm{e}\end{array}$ \\
\hline OprL & $\begin{array}{l}\text { F:ATGGAAATGCTGAAATTCTCT } \\
\text { GCT } \\
\text { R:CTTCTTCAGCTCGACGCGACG }\end{array}$ & 30 & $\begin{array}{l}5 \\
5 \\
\end{array}$ & 504 & $\begin{array}{l}\text { (Vos et al., } \\
1997)\end{array}$ \\
\hline ToxA & $\begin{array}{l}\text { F:GACAACGCCCTCAGCATCACC } \\
\text { AGC } \\
\text { R:CGCTGGCCCATTCGCTCCAGC } \\
\text { GCT }\end{array}$ & 35 & $\begin{array}{l}6 \\
7\end{array}$ & 396 & $\begin{array}{l}\text { (Najafi, } \\
\text { Kafil, } \\
\text { Shokrian, } \\
\text { \& Azimi,, } \\
\text { 2015b) }\end{array}$ \\
\hline LasB & $\begin{array}{l}\text { F:ACAGGTAGAACGCACGGTTG } \\
\text { R: GATCGACGTGTCCAAACTGC }\end{array}$ & 30 & $\begin{array}{l}5 \\
0\end{array}$ & $\begin{array}{c}122 \\
0\end{array}$ & $\begin{array}{l}\text { (Najafi et } \\
\text { al., 2015b) }\end{array}$ \\
\hline LasA & $\begin{array}{l}\text { F: GCAGCACCAAAGATCCC } \\
\text { R: GAAATGCAGGTGCGGTG }\end{array}$ & 30 & $\begin{array}{l}5 \\
7\end{array}$ & $\begin{array}{c}107 \\
5\end{array}$ & $\begin{array}{l}\begin{array}{c}\text { Najajai it } \\
\text { al., 2015b) }\end{array} \\
\text { (a) }\end{array}$ \\
\hline
\end{tabular}

\section{G. Statistical Analysis}

All data were computerized and analyzed using Microsoft excel version 2010. Percentages were used for bacterial isolation, biofilm and antibiotics resistance. Statistical significant were calculated at 0.05 level using Chi-Square online program.

\section{Results}

\section{Isolation Rate of Pseudomonas aeruginosa}

In general, the bacterial growth was observed in $30(83.4 \%)$ out of 36 ear swabs, $4(11.1 \%)$ revealed no growth, while the remaining $2(5.6 \%)$ revealed yeast (Candida albicans). Thirty ear swabs samples showed growth of four bacterial species, P.aeruginosa, S.aureus, proteus spp. and E.coli, table (2). P.aeruginosa was predominant species $11 / 30(36.7 \%)$ when compared with an isolation rate of other bacterial species which collectively constitute 19/30(63.3\%). P.aerugniosa was isolated in pure culture in $8 / 11(72.7 \%)$, while $3 / 11(27.3 \%$ ) were in mixed growth with other bacterial species. On the other hand, Proteus spp. and E. coli were found only in mixed growth.

Table(2): P.aeruginosa isolation rate from patient with Chronic Suppurative Otitis Media

\begin{tabular}{|c|c|c|c|c|c|}
\hline \multirow{2}{*}{$\begin{array}{c}\text { No. of } \\
\text { ear } \\
\text { swabs }\end{array}$} & \multicolumn{3}{|c|}{ Bacterial Growth } & \multicolumn{2}{c|}{ No bacterial growth } \\
\cline { 2 - 4 } & P.aeruginosa & $\begin{array}{c}\text { Other bacterial } \\
\text { species }\end{array}$ & $\begin{array}{c}\text { Fungal } \\
\text { Growth }\end{array}$ & $\begin{array}{c}\text { No } \\
\text { growth } \\
\text { at all }\end{array}$ \\
\cline { 2 - 4 } & Pure & Mixed & Species & No. & Specing \\
\hline
\end{tabular}

\begin{tabular}{|c|c|c|c|c|c|c|}
\hline \multirow{3}{*}{36} & \multirow{3}{*}{$8(72.7)$} & \multirow{3}{*}{$3(27.3)$} & S.aureus & 8 & \multirow{5}{*}{$2(5.6)$} & \multirow{5}{*}{$4(11.1)$} \\
\hline & & & $\begin{array}{c}\text { Proteus } \\
\text { spp }\end{array}$ & 6 & & \\
\hline & & & E.coli & 5 & & \\
\hline $\begin{array}{l}\text { Sub- } \\
\text { Total }\end{array}$ & \multicolumn{2}{|c|}{$11(36.7 \%)$} & \multicolumn{2}{|c|}{$19(63.3)$} & & \\
\hline $\mathrm{P}$-value & \multicolumn{4}{|c|}{$p>0.05$} & & \\
\hline total & \multicolumn{4}{|c|}{$30(83.4)$} & \multicolumn{2}{|c|}{$6(1.7 \%)$} \\
\hline
\end{tabular}

In regard with the type of microbial infection table(3), this study found that $14 / 30(46.7 \%)$ were mono-microbial infection, majority of these infection $8(57.1 \%)$ were accounted to P.aeruginosa, while only $6(42.9 \%)$ were caused by S.aureus with no statistical differences( $\mathrm{P}>0.05)$.

\section{Table(3):Poly-microbial and Mono-Microbial infections of Chronic Suppurative Otitis Media}

The ear swabs that yield polymicrobial growth $16(53.4 \%)$, P.aeruginosa was found in $3(18.7 \%)$ of these samples. Statistically significant differences $(\mathrm{p}<0.05)$ was found between poly-microbial infections with P.aeruginosa and those for other bacterial species.

\section{Molecular study \\ Identification of P.aeruginosa}

The results of amplification of identification gene (oprL) revealed, that all $(100 \%)$ phenotypically and biochemically identified P.aeruginosa were positive for oprL gene which identify the bacterium to species level. Figure (1).

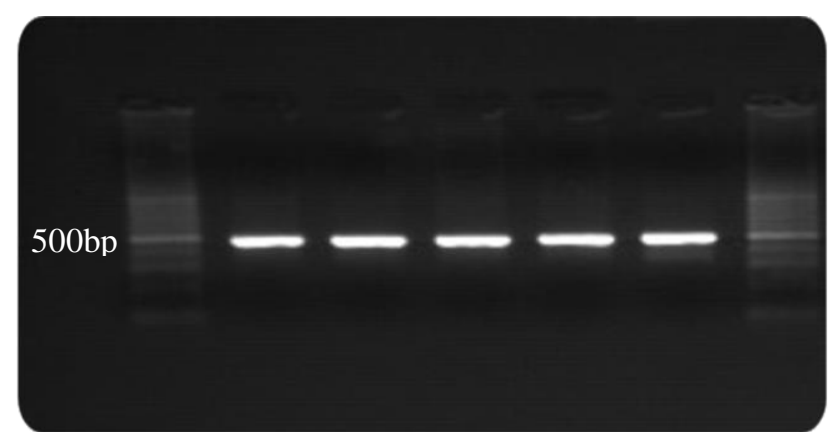

Figure(1): Product of oprL gene after electrophoresis in agarose gel(2\%) under $105 \mathrm{~V}$ for 55 minutes. M, molecular marker(1Kbp), lanes, $1,2,3,4,5$, the product size (504bp).

Molecular Screening of Virulence genes

Virulence genes were detected in all Paeruginosa stains with varying rates (figure 2). The most frequently detected virulence gene was ToxA 10/11(90.1\%), followed by LasB 9/11 (81.8\%) and LasA 7/11(63.6\%). The expected products of ToxA, LasB and LasA genes were presented in figures $(3,4,5$, respectively).

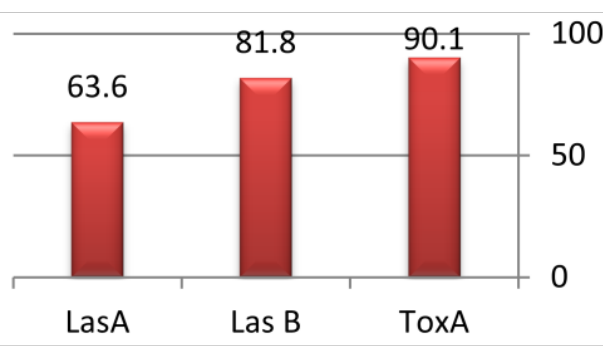


Figure(2): Detection rates of the three virulence genes in P.aeruginosa isolated from patients of Chronic Sunnurative Otitis Media (CSOM).

Based on the combination of three virulence genes, the eleven P.aeruginosa isolates were categorized into four genotypes, table (4). Most strains of P.aeruginosa $7 / 11(63.6 \%)$ in the studied population were belong to genotype (ToxA+ LasA+ Las $\mathrm{B}+$ ) that harbour the three virulence gens, and $2 / 11(18.2 \%)$ were belong to pathotype (ToxA+ LasA- Las B+) that harbour tow virulence genes (exotoxin $\mathrm{A}$ and protease). The genotype that has a combination of exotoxin A and elastase A (ToxA+ LasA+LasB- ) and the genotype that harbour only exotoxin A (ToxA+ LasA- LasB-) was found in low percentage $(9.1 \%)$.

Table(4): genotypes of P.aeruginosa isolated from CSOM based on different combination of virulence

\begin{tabular}{|c|c|c|}
\hline genotypes & No. of isolates & $\%$ \\
\hline ToxA $^{+}$LasA $^{-} \quad$ LasB $^{-}$ & 1 & $9.1 \%$ \\
\hline $\operatorname{ToxA}^{+}$LasA $^{+}$las $B^{-}$ & 1 & $9.1 \%$ \\
\hline ToxA $^{+}$LasA $^{-} \quad$ Las $B^{+}$ & 2 & $18.2 \%$ \\
\hline ToxA $^{+}$LasA $^{+}$Las $^{+}$ & 7 & $63.6 \%$ \\
\hline Total & 11 & \\
\hline
\end{tabular}

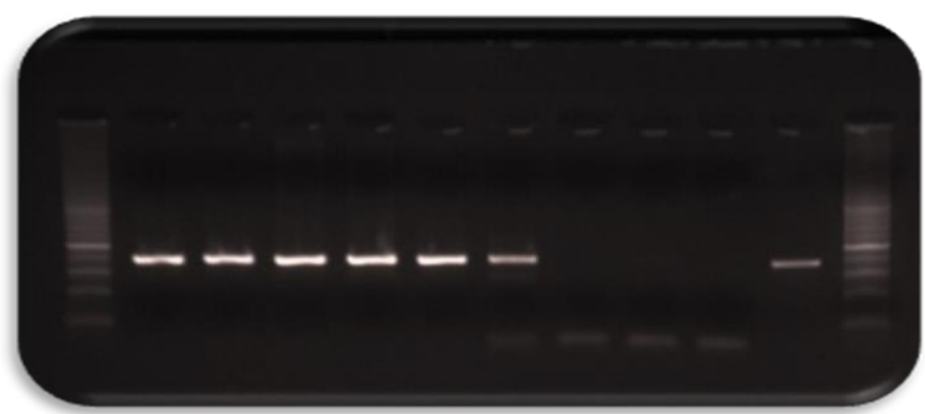

Figure(3): Product of ToxA gene after electrophoresis in agarose gel $(2 \%)$ under $105 \mathrm{~V}$ for 55 minutes which give product size396bp. $\mathrm{M}$, molecular marker (1Kbp), lanes, $1,2,3,4,5,6$ and 10 positive amplification. Lans 7,8 and 9 negative control.

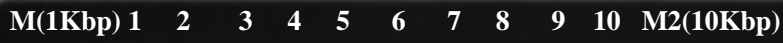
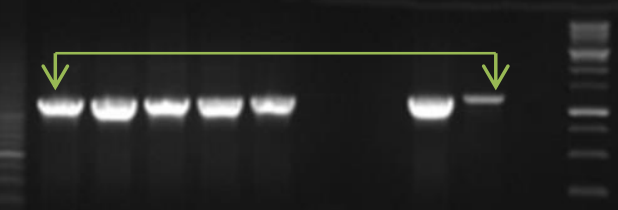

Las B gene product $1220 \mathrm{bp}$

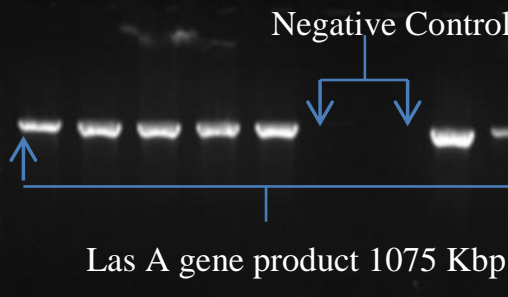

Figure(5): product of lasA gene after electrophoresis in agarose gel $(2 \%)$ under $105 \mathrm{~V}$ for 55 minutes which give product size 1075bp. M,molecular marker , lanes, 1,2,3,4,5,8,9 positive amplification. Lanes 6,7,10 negative control.

\section{Antibiotics resistance profile}

The results of the antibiogram analysis are illustrated figure (6). The highest resistance was recorded against Erythromycin, Ciprofloxacin $(63.1 \%)$ and Trimethoprim $(57.9 \%)$. Also, this study found the resistance to Gentamycin, Ofloxacin and Ceftriaxone were(47.4\%, $47.3 \%$ and $42.1 \%$ respectively). Most isolates (60.\%) were susceptible to Piperacillin-tazobactam.

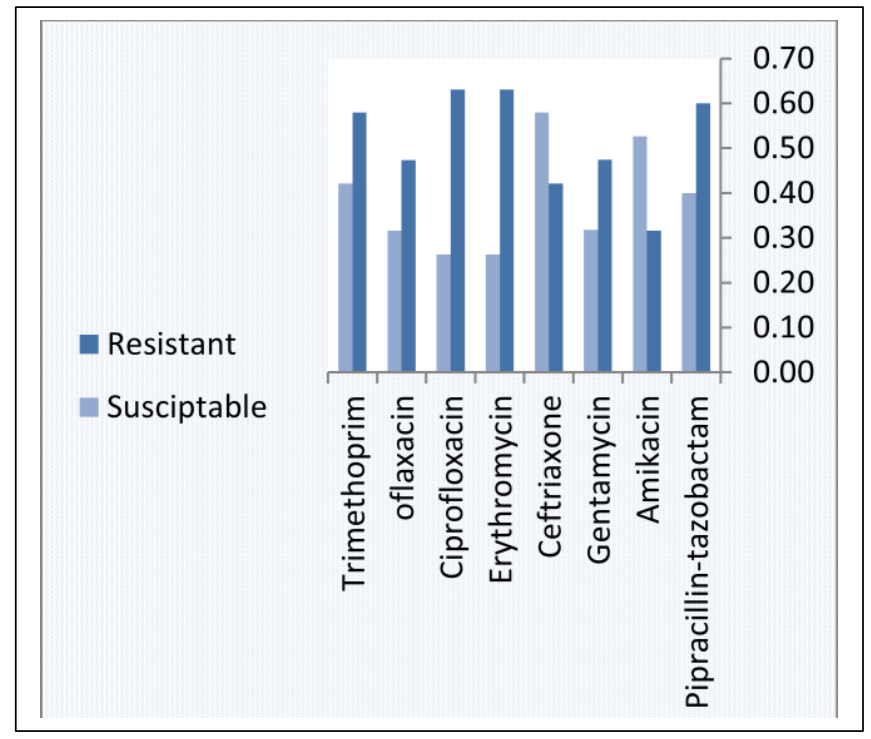

Figure(6): Antibiogram of P.aeruginosa isolated from CSOM patients

\section{Biofilm production}

This study found that all P.aeruginosa strains (100\%) were biofilm producer with varying strength. Most strains 8/11(72.7\%) were strong producer, and 3/11(27.3\%) were moderate biofilm producer. Table,(5). According to genotypes, the production of biofilm correlate with occurrence of virulence genes. According to the results of this study (table,5), the strong biofilm production was found at high percentage $(75 \%$ )in the genotype that harbor three

Figure(4):Product of lasB gene after electrophoresis in agarose gel (2\%) under $105 \mathrm{~V}$ for 55 minutes which give product size $1220 \mathrm{bp}$. M1(1Kbp),M2 (10Kbp) molecular markers. Lanes, 1,2,3,4,5, 8,9 
virulence genes( ToxA+LasA+ Las $B+)$. Only one strain (12.5\%) of each genotype (ToxA+ LasA-Las B+) and genotype (ToxA+LasA+las $B$-) was strong biofilm producer. While, the genotype ToxA+LasA-LasB-that harbored only one virulence gene (ToxA gene) was moderate biofilm producer.

Table(5): biofilm production of four genotypes of P.aeruginosa strains isolated from patients of CSOM.

\begin{tabular}{|c|c|c|c|}
\hline \multirow[b]{2}{*}{ genotypes } & \multicolumn{3}{|c|}{ Biofilm Production Strength } \\
\hline & $\begin{array}{c}\text { Weak } \\
(\%)\end{array}$ & $\begin{array}{c}\text { Moderate } \\
(\%)\end{array}$ & $\begin{array}{c}\text { Strong } \\
(\%)\end{array}$ \\
\hline ToxA $^{+}$LasA $^{-}$LasB $^{-}$ & - & 1 & $0(0 \%)$ \\
\hline ToxA $^{+}$LasA $^{+}$lasB $B^{-}$ & 0 & 0 & $1(12.5 \%)$ \\
\hline $\operatorname{ToxA}^{+} \operatorname{Las}^{-} \operatorname{Las}^{+}$ & 0 & 1 & $1(12.5 \%)$ \\
\hline $\operatorname{ToxA}^{+} \operatorname{Las}^{+} \operatorname{Las} B^{+}$ & 0 & 1 & $6(75 \%)$ \\
\hline Total & 0 & $3(27.3 \%)$ & $8(72.7 \%)$ \\
\hline
\end{tabular}

\section{Discussion}

The present study focused on the molecular characterization of P.aeruginosa as the most common cause CSOM, along with an investigation of its ability to resist most commonly used antibiotics. This study found that the bacterial infection rate $(83.4 \%)$ was higher than the fungal recovery rate $(5.2 \%)$. This finding was in agreement with other studies (Madana, Yolmo, Kalaiarasi, Gopalakrishnan, \& Sujatha, 2011; Rajat P, Deepak J, 2013; Seid, Deribe, Ali, \& Kibru, 2013), as it has been accepted that bacterial infections are the most common cause of SCOM(Mittal et al., 2015b; Verhoeff, Van Der Veen, Rovers, Sanders, \& Schilder, 2006). The low infection rate of fungal species in this study could be contributed to the climate of Iraq particularly, south of country ( Thi-Qar province, were the study conducted) which is not humid this explanation depend on the fact that, only regions with high humidity recorded high fungal recovery in patients with CSOM (Verhoeff et al., 2006). The finding of this study regarding the P.aeruginosa predominance in CSOM was in agreement with local studies; Alsaimary, et al (19.4\%)27AlHilli,201528, Aldhaher and Hassan,2018(Aldhaher \& Hassan, 2018; Arwa Hammodi Karim, 2005). Similarly, the finding of this study regarding the predominance of P.aeruginosa was also in agreement with other global studies(Chirwa et al., 2015; Madana et al., 2011; Rath, Das, $\&$ Padhy, 2017). The predominance of P.aeruginosa in CSOM can be accounted to their minimal nutritional requirement and potential ability to resist antibiotics(Pollock .M, 1996). On the other hand, in contrast to Sied A, et al .2013; Seid et al., 2013; and Molla R et al .,2019, who reported that Portues spp. was the most prevalent species among CSOM patients. This variation could be attributed to the small sample size of this study population, anaerobic bacterial species which not included in this study and geographical variation. Finding of this study regarding the type of microbial infections (Poly-microbial \& MonoMicrobial) was inconsistent with Al-marzoqi A.H, et al.,2013; Al-marzoqi, Hussein, Mohammad, Taee, \& Yheea,
2013, who found that poly-microbial infection was higher than monomicrobial infection. In this regard results of the current study was in harmony with the well-known fact that microbial infection of the ear usually polymicrobial (Bakaletz, 2010; Mittal et al., 2015b). For precise identification of Pseudomonas spp to species level, lipoprotein L (OprL) gene was selected with specific primer designated by Vos et al., 1997, this primer showed great specificity to detect Pseudomonas to species level and it is applicable for routine detection of $P$. aeruginosa in clinical samples, has been used in several studies; Najafi et al., 2015b; Neamah \& Department, 2017).

In this study all P.aeruginosa (100\%) showed positive for at least one virulence genes. The detection rate of ToxA gene $90.1 \%$ was in consistence with the result obtained by Auda et al .,(2015) ;Auda, Kadmy, Naseer, Ali, \& Muslim, 2015; and Neamah \& Department, (2017). Most P.aeruginosa $(81.9 \%)$ in this study harbour gene (LasB) which coded for elastase enzyme, this result was in agreement with Al-Shwaikh,(2019); Al-Shwaikh \& AlArnawtee, 2019 who found that the detection rate of this gene $82 \%$ in otitis media samples. Production of biofilm was found in all P.aeruginosa strains, this finding was in agreement with Dohar J.E.,(2005); Dohar et al., (2005) who concluded in his study that the CSOM is a biofilm disease. Similarly, finding of this study was in agreement with Abdelshafy I.A (2015) . on the other hand, our finding was higher than those recorded by Pinar et al ., (2008) and Lee et al .,(2009). The higher biofilm percentage in this study could be explained by the type of bacterial species as this study focused on P.aeruginosa which is known to have a high propensity of biofilm production. It is estimated that about $10 \%$ of P.aeruginosa virulence genes are controlled by quorum sensing (QS) system. The cell survival, biofilm production and virulence factors are depending on these quorum sensing, particularly, lasl QS regulates the biofilm production and secretion system II ( both LasA and LasB produce through this system) 16 . Thus this could explain the high biofilm propensity of strains that harbour the three virulence factors (ToxA+LasA+Las $B+)$.

Currently, the modality of treatment of CSOM depend on the aural toilet in combination with topical and systemic antibiotics. Some antimicrobial solutions are used such as acetic acid, Aluminum acetate and Iodine in resolving otoreah, unfortunately these solutions were not included in this study. The current study, found high resistance rate against commonly used ototic antiobiotics including; Ciprofloxacin, Ofloxacin which are considered first line treatment of CSOM. This finding was in agreement with Rath.S, et al .,(2017).

\section{REFERENCES}

CLSI supplement M100. Wayne, P. C. and L. S. I. (2017). CLSI. Performance Standards for Antimicrobial Susceptibility Testing.

Ahmad, S. (2013). Antibiotics in chronic suppurative otitis media: A bacteriologic study. Egyptian Journal of Ear, Nose, Throat and Allied Sciences, 14, 191-194. 
Al-Hilli, Z. B. (2015). Study of Bacterial Isolates and their Susceptibility Pattern in Chronic Suppurative Otitis Media. IOSR Journal of Pharmacy and Biological Sciences Ver. I, 10(6), 2319-7676. https://doi.org/10.9790/3008$\underline{10610105}$

Al-marzoqi, A. H., Hussein, H. J., Mohammad, Z., Taee, A., \& Yheea, S. K. (2013). Otitis Media; Etiology and Antibiotics Susceptibility among Children under Ten Years Old in Hillah city, Iraq. 3(3), 1-8.

Al-Shwaikh, R. M. A., \& Al-Arnawtee, A. F. (2019). Detection of lasB Gene of Pseudomonasaeruginosa Causing Different Infection. Al-Nahrain Journal of Science, 00(2), 48-52. https://doi.org/10.22401/anjs.00.2.07

Aldhaher, Z., \& Hassan, H. F. (2018). Bacterial isolates and antibiotic susceptibility of ear infections in Iraqi patients. International Journal of Biosciences (IJB), 13(01), 292-297. https://doi.org/10.12692/ijb/13.1.292-297

Alsaimary, I. E., Alabbasi, A. M., \& Najim, J. M. (2010). Antibiotics susceptibility of bacterial pathogens associated with otitis media. Journal of Bacteriological Research, 2(4), 41-50.

Arwa Hammodi Karim. (2005). Effect of Tris-EDTA and ascorbate in increasing antibiotic activity against bacteria isolated from Otitis Media.

Auda, I. G., Kadmy, I. M. S. A. L., Naseer, A., Ali, M., \& Muslim, S. N. (2015). toxA gene as a chromosomal marker for rapid identification of Otitis media Pseudomonas aeruginosa. International Journal of Advances in Chemical Engineering and Biological Sciences, 2(1), 28-31. https://doi.org/10.15242/ijacebs.c0815022

Bakaletz, L. O. (2010). Immunopathogenesis of polymicrobial otitis media. J Leukoc Biol, 87, 213-222.

Chirwa, M., Mulwafu, W., Aswani, J. M., Masinde, P. W., Mkakosya, R., \& Soko, D. (2015). Microbiology of chronic suppurative otitis media at Queen Elizabeth central hospital, Blantyre, Malawi: A cross-sectional descriptive study. Malawi Medical Journal, 27(4), 120-124. https://doi.org/10.4314/mmj.v27i4.1

Dohar, J. E., Hebda, P. A., Veeh, R., Awad, M., Costerton, J. W., Hayes, J., \& Ehrlich, G. D. (2005). Mucosal Biofilm Formation on Middle-Ear Mucosa in a Nonhuman Primate Model of Chronic Suppurative Otitis Media. The Laryngoscope, 115(August), 1469-1472. https://doi.org/10.1097/01.mlg.0000172036.82897.d4

Ettehad, G. H., Refahi, S., Nemmati, A., Pirzadeh, A. \& Daryani, A. (2006). Microbial and antimicrobial susceptibility patterns from patients with chronic otitis media in Ardebil. Int J Trop Med, 1, 62-65.

Gellatly, S. L., \& Hancock, R. E. W. (2013). Pseudomonas aeruginosa: New insights into pathogenesis and host defenses. Pathogens and Disease, 67(3), 159-173. https://doi.org/10.1111/2049-632X.12033

J.C. Post, P. Stoodley, L. Hall-Stoodley, G. D. E. (2004). The role of biofilms in otolaryngologic infections. Curr. Opin. Otolaryngol. Head Neck Surg, 12(3), 185-190.

Li, M. G., Hotez, P. J., Vrabec, J. T., \& Donovan, D. T. (2015). Is Chronic Suppurative Otitis Media a Neglected Tropical Disease? PLoS Neglected Tropical Diseases, 9(3), 1-6. https://doi.org/10.1371/journal.pntd.0003485

Madana, J., Yolmo, D., Kalaiarasi, R., Gopalakrishnan, S., \& Sujatha, S. (2011). Microbiological profile with antibiotic sensitivity pattern of cholesteatomatous chronic suppurative otitis media among children. International Journal of Pediatric Otorhinolaryngology, 75(9), 11041108. https://doi.org/10.1016/j.ijporl.2011.05.025

Mittal, R., Lisi, C. V., Gerring, R., Mittal, J., Mathee, K., Narasimhan, G., ... Liu, X. Z. (2015a). Current concepts in the pathogenesis and treatment of chronic suppurative otitis media. Journal of Medical Microbiology, 64(10), 1103-1116. https://doi.org/10.1099/jmm.0.000155

Mittal, R., Lisi, C. V, Gerring, R., Mittal, J., Mathee, K., Narasimhan, G., ... Liu, X. (2015b). Current concepts in the pathogenesis and treatment of chronic suppurative otitis media. 1103-1116. https://doi.org/10.1099/jmm.0.000155

Molla, R., Tiruneh, M., Abebe, W., \& Moges, F. (2019). Bacterial profile and antimicrobial susceptibility patterns in chronic suppurative otitis media at the University of Gondar Comprehensive Specialized Hospital, Northwest Ethiopia. BMC Research Notes, 12(1), 1-6. https://doi.org/10.1186/s13104-019-4452-4

Najafi, K., Kafil, H. S., Shokrian, S., \& Azimi, S. (2015a). Virulence genes and antibiotic resistance profile of Pseudomonas aeruginosa isolates in Northwest of Iran Virulence Genes and Antibiotic Resistance Profile of Pseudomonas aeruginosa Isolates in Northwest of Iran. (May).

Najafi, K., Kafil, H. S., Shokrian, S., \& Azimi, S. (2015b). Virulence genes and antibiotic resistance profile of Pseudomonas aeruginosa isolates in Northwest of Iran Virulence Genes and Antibiotic Resistance Profile of Pseudomonas aeruginosa Isolates in Northwest of Iran. JOURNAL OF PURE AND APPLIED MICROBIOLOGY, 9(Spl.Edn.1), 383-389.

Neamah, A. A., \& Department. (2017). Molecular Detection of virulence factor genes in pseudomonas aeruginosa isolated from human and animals in Diwaniya province. Kufa Journal For Veterinary Medical Sciences, 8(1), 218-230.

Orji FT. (2013). A Survey of the Burden of Management of Chronic Suppurative Otitis Media in a Developing Country. Ann Med Health Sciences Res, 3, 598-601. https://doi.org/10.4103/2141-9248.122126 
Pollock .M. (1996). Special role Pseudomonas aeruginosa in CSOM workshop on CSOM etiology and management. Ann. Otorhinolaryngol, 17, 6.

Rajat P, Deepak J, V. N. et al. (2013). Microbiology of Chronic Otitis media in a Tertially Care Setup of Utterrakhand State. N Am J Med Sci, 5(4), 282-285.

Rath, S., Das, S. R., \& Padhy, R. N. (2017). Vigilância de bactérias Pseudomonas aeruginosa e MRSA associadas à otite média crônica supurativa. Brazilian Journal of Otorhinolaryngology, 201-206. https://doi.org/10.1016/j.bjorl.2016.03.008

Seid, A., Deribe, F., Ali, K., \& Kibru, G. (2013). Bacterial otitis media in all age group of patients seen at Dessie referral hospital, North East Ethiopia. Egyptian Journal of Ear, Nose, Throat and Allied Sciences, 14(2), 7378. https://doi.org/10.1016/j.ejenta.2013.02.005

Verhoeff, M., Van Der Veen, E. L., Rovers, M. M., Sanders, E. A. M., \& Schilder, A. G. M. (2006). Chronic suppurative otitis media: A review. International Journal of Pediatric Otorhinolaryngology, 70(1), 1-12. https://doi.org/10.1016/j.ijporl.2005.08.021

Vos, D. D. E., Lim, A., Pirnay, J., Struelens, M., Vandenvelde, C., Duinslaeger, L. U. C., ... Cornelis, P. (1997). Direct Detection and Identification of Pseudomonas aeruginosa in Clinical Samples Such as Skin Biopsy Specimens and Expectorations by Multiplex PCR Based on Two Outer Membrane Lipoprotein Genes, oprI and oprL. JOURNAL OF CLINICAL MICROBIOLOGY, 35(6), 1295-1299.

Wang, J. C., Hamood, A. N., Saadeh, C., Cunningham, M. J., Yim, M. T., \& \& Cordero, J. (2014). Strategies to prevent biofilm-based tympanostomy tube infections. Int $\mathrm{J}$ Pediatr Otorhinolaryngol, 78, 1433-1438.

World Health Organization. (2003). Chronic suppurative otitis media Burden of Illness and Management Options (Vol. 4). https://doi.org/10.1007/978-94-011-6663$\underline{8} 3$

\title{
التوصيف الجزيئي لعوامل ضراوة و مقاومة المضادات الحياتية لبكتريا الزوائف الزنجارية المعزولة من الانن

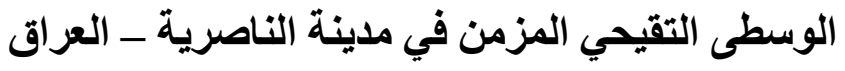

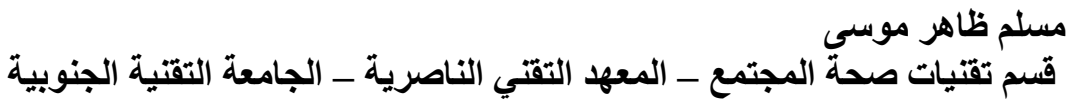

اجريت هذ الدراسة لتوصيف فوعة بكتريا الزوائف الزنجارية المعزولة من اصابات التهاب الاذن الوسطى القيحي المزمن في منطقة محددة من جنوب العراق التوات ، مدينة

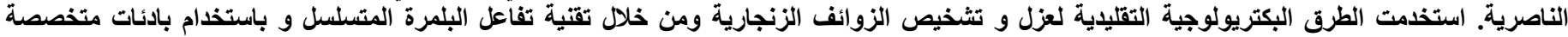

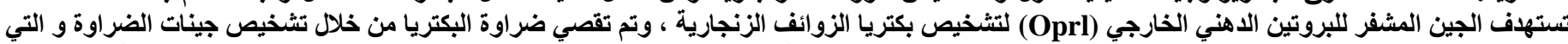

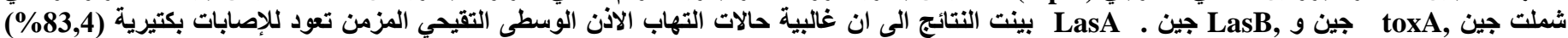

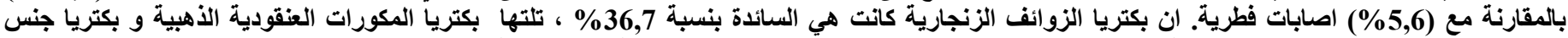

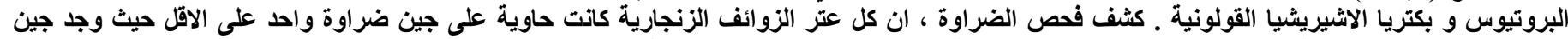

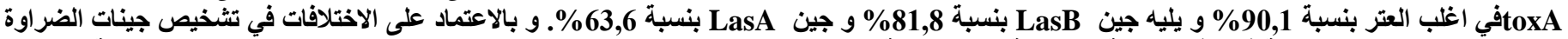

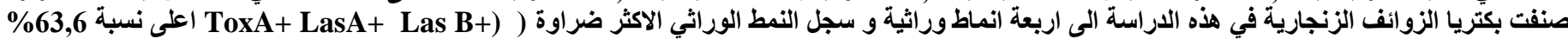

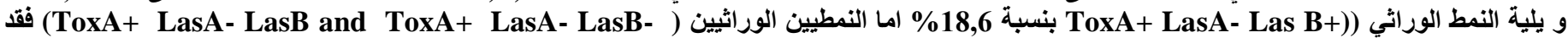

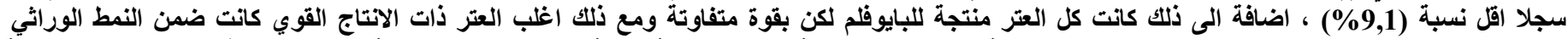

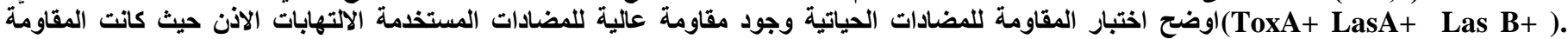

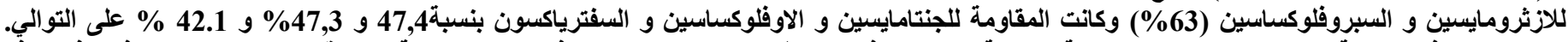

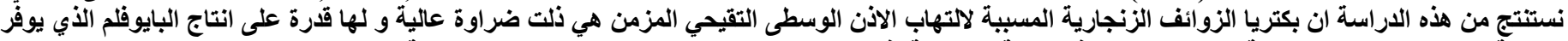

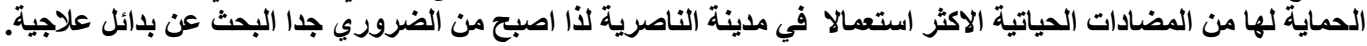

